\title{
BUDŻET ZADANIOWY JAKO NOWA METODA ZARZĄDZANIA FINANSAMI PUBLICZNYMI
}

Reaktywowany w Polsce w 1990 r. samorząd jest oparty na doświadczeniach samorządów lokalnych Europy Zachodniej. Występujący podział zadań publicznych w powstałych strukturach między organy administracji rządowej i samorządowej (województwa, powiaty i gminy) pociąga za sobą także konieczność podziału dochodów publicznych.

Bez właściwie dokonanego podziału dochodów publicznych jednostki samorządu terytorialnego, które w myśl konstytucji realizują istotną część zadań publicznych, mogą stać się niezdolne do wykonania nałożonych na nich obowiązków. Obecnie samorządy działają w szybko zmieniającym się środowisku, co zmusiło władze do efektywnego zarządzania tymi jednostkami. W zarządzaniu tym szczególną rolę odgrywa zarządzanie finansami, w którym znajdują odzwierciedlenie wszystkie decyzje podejmowane w jednostce samorządu terytorialnego.

Należy podkreślić, że skuteczność, powodzenie oraz aktywność władz samorządowych w rozwoju jednostki w dużym stopniu zależą od umiejętności, kwalifikacji i doświadczenia władz samorządowych. Jednymi z ważniejszych narzędzi są między innymi możliwość kształtowania budżetu gminnego, zarządzanie majątkiem komunalnym, możliwość planowania w zakresie rozwoju lokalnego, możliwość wspierania sektora małej i średniej przedsiębiorczości. Nieodzownym czynnikiem, katalizatorem rozwoju lokalnego są oczywiście środki finansowe, stanowiące podstawę realizacji planowanych zadań. Planowanie i realizacja wydatków ze środków publicznych to jedno z największych wyzwań związanych z zarządzaniem publicznym. Podczas planowania należy wybrać najlepszą alokację środków publicznych z uwzględnieniem zgłaszanych potrzeb społeczno-gospodarczych.

Celem niniejszego artykułu jest ukazanie budżetu zadaniowego jako nowej metody zarządzania finansami publicznymi: począwszy od budżetu centralnego, a skończywszy na budżetach najniższego szczebla. Szczególną uwagę zwrócono na cele i zadania budżetu, jak również jego mierniki pozwalające na ocenę jego efektywności. Publikacja ma charakter teoretyczny i odnosi się do analizy kwestii budżetu zadaniowego na gruncie finansów publicznych, zwłaszcza w kontekście budżetu centralnego państwa.

Słowa kluczowe: rząd, władze lokalne, finanse publiczne, budżet, zadania publiczne.

\section{WPROWADZENIE}

Współcześnie jednostki samorządu terytorialnego działają w szybko zmieniającym się otoczeniu, co wymusza na ich władzach sprawne zarządzanie. Szczególna rola przypada tutaj zarządzaniu finansami ${ }^{3}$.

\footnotetext{
${ }^{1}$ Antoni Olak, prof. nadzw. dr hab. Wyższa Szkoła Biznesu i Przedsiębiorczości w Ostrowcu Św. Katedra Bezpieczeństwa Narodowego, ul. Akademicka 12 (os. Pułanki), 27-400 Ostrowiec Św., e-mail: antonio130@vp.pl

2 Bożena Sowa, dr, Wyższa Szkoła Prawa i Administracji w Przemyślu, Zamiejscowy Wydział Prawa i Administracji w Rzeszowie, Katedra Nauk o Zarządzaniu i Ekonomii; ul. Cegielniana 14, 35-505 Rzeszów; e-mail: bozenas@wspia.eu, tel.: 0178670488 (autor korespondencyjny)
} 
Występujący w powstałych strukturach podział zadań publicznych między organy administracji rządowej i samorządowej (województwa, powiaty i gminy) pociąga za sobą także konieczność podziału dochodów publicznych. Stanowią one kluczową, materialną bazę wykonywania zadań publicznych ${ }^{4}$. Bez właściwie dokonanego podziału dochodów publicznych jednostki samorządu terytorialnego, które w myśl konstytucji ${ }^{5}$ realizują istotną część zadań publicznych, mogą stać się niezdolne do wykonania nałożonych na nich obowiązków ${ }^{6}$.

W zakresie finansów znajdują odzwierciedlenie wszystkie decyzje podejmowane w jednostce samorządu terytorialnego. Efektywność tego zarządzania wymaga gospodarowania środkami publicznymi w sposób zapewniający wydatkowanie tych środków zgodnie z celami i zadaniami o charakterze publicznym ${ }^{7}$.

Celem niniejszego artykułu jest ukazanie budżetu zadaniowego jako nowej metody zarządzania finansami publicznymi, począwszy od budżetu centralnego, a skończywszy na budżetach najniższego szczebla. Szczególną uwagę zwrócono na cele i zadania budżetu, jak również jego mierniki pozwalające na ocenę jego efektywności.

\section{BUDŻET ZADANIOWY - ISTOTA I ZAŁOŻENIA}

Planowanie i realizacja wydatków ze środków publicznych to jedno z największych wyzwań związanych z zarządzaniem publicznym ${ }^{8}$. Podczas planowania należy wybrać najlepszą alokację środków publicznych z uwzględnieniem zgłaszanych potrzeb społeczno-gospodarczych. Przy wyborze celów, które mają być realizowane za pomocą środków publicznych, należy uwzględnić możliwości strategiczne rozwoju państwa oraz jednostek samorządowych niższego szczebla, a także uwarunkowania wewnętrzne i zewnętrzne w kontekście wieloletniej perspektywy.

Jednym z kluczowych narzędzi umożliwiających doskonalenie systemu zarządzania finansami jednostek samorządu terytorialnego jest budżet zadaniowy stanowiący metodę zarządzania finansami publicznymi stosowaną w systemach finansów publicznych wielu

\footnotetext{
${ }^{3}$ Szerzej P. Dziekański, Gospodarka finansowa powiatów województwa świętokrzyskiego w świetle polskiego prawa i danych ekonomicznych, [w:] Ekonomiczne i organizacyjne instrumenty wspierania rozwoju lokalnego i regionalnego. Przedsiębiorczość, instytucje wsparcia i gospodarka finansowa, red. B. Filipiak, ,Zeszyty Naukowe” 2008/500, „Ekonomiczne Problemy Usług” 21, s. 302-312.

${ }^{4}$ Szerzej A. Olak, Terytorialny marketing mix - produkt, cena, dystrybucja, promocja, [w:] A. Olak, P. Dziekański, S. Pytka, Marketing Terytorialny - gmina i jej promocja, Multiprint, S.R.O, Kośice-Ostrowiec-Zagnańsk 2014, s. 26-34.

${ }^{5}$ Konstytucja Rzeczypospolitej Polskiej z 2 kwietnia 1997 r. (DzU 1997, nr 78, poz. 483 ze zm.).

${ }^{6}$ Szerzej B. Sowa, Budżet jednostki samorządu terytorialnego jako podstawa planowania przedsięwzięć inwestycyjnych, [w:] Przedsiębiorczość. Uwarunkowania i przejawy w procesie funkcjonowania samorzadu terytorialnego, „Podręczniki Uczelniane” 113, red. K. Jaremczuk, L. Kliszczak, W. Kalita, R. Kostelecki, M. Kurek, W. Kuźniar, P. Niemczuk, B. Sowa, J. Strojny, Wyższa Szkoła Prawa i Administracji w Przemyślu, PrzemyślRzeszów 2012, s. 131-150.

${ }^{7}$ Zob. A. Kister, A. Zbroja, Budżet zadaniowy jako forma kontroli zarządzania finansami jednostki samorzqdu terytorialnego, „Zeszyty Naukowe WSEI. Ekonomia” 2012/2.

${ }^{8}$ Szerzej P. Dziekański, Wptyw polityki budżetowej jednostek samorządu terytorialnego na rozwój regionu świętokrzyskiego, [w:] Konkurencyjność i innowacyjność regionów w warunkach globalizacji i metropolizacji przestrzeni, red. J. Kot, Akademia Świętokrzyska w Kielcach, Wydział Zarządzania i Administracji, Instytut Ekonomii, Kielce 2007, s. 183-191; B. Sowa, Gospodarka finansowa gminy-wybrane aspekty, [w:] Samorzad gminy $w$ świetle badań empirycznych, red. J. Posłuszny, Z. Czarnik, Wyższa Szkoła Prawa i Administracji, Przemyśl-Rzeszów 2014, s. 256-263.
} 
krajów członkowskich Organizacji Współpracy Gospodarczej i Rozwoju (OECD, Organization for Economic Cooperation and Development), a także zalecaną przez Komisję Europejską ${ }^{9}$ Istotą budżetu zadaniowego jest wprowadzenie zarządzania wydatkami publicznymi przez odpowiednio skonkretyzowane i zhierarchizowane cele na rzecz osiągnięcia określonych rezultatów, mierzonych za pomocą ustalonego systemu mierników ${ }^{10}$.

Istota budżetu zadaniowego sprowadza się zatem do tego, że ${ }^{11}$ :

- budżet jest traktowany jako plan sfinansowania dokładnie określonej listy zadań publicznych;

- każdemu z zadań finansowanych środkami ujętymi w budżecie przypisana jest nie tylko kwota środków, które mogą być wydatkowane na realizację danego zadania, ale i wskaźniki wykonania zadań, których osiągnięcie jest celem - ma mu służyć dokonywanie wydatków publicznych i powinien on być osiągnięty w danym roku budżetowym;

- rozliczenie organu wykonawczego z wykonania budżetu polega na jednoczesnym sprawdzeniu przestrzegania limitów wydatków i stopnia wykonania założonych zadań, a nieosiągnięcie wyznaczonych celów, mimo wykorzystania pełnego limitu wydatków, traktowane jest w istocie rzeczy tak samo jak przekroczenie limitu wydatków.

Odnosząc pojęcie budżetu zadaniowego do jednostek samorządu terytorialnego, można powiedzieć, że budżet zadaniowy stanowi nowoczesną formę zarządzania finansami tych jednostek. Nie jest to jedynie dokument końcowy, ale całościowy system planowania, wykonywania oraz sprawozdawczości. Zakres informacji, który opisowo jest podawany w budżecie zadaniowym, umożliwia społeczności lokalnej oraz inwestorom „,wyrobienie" własnego zdania odnośnie do kondycji finansowej danej jednostki samorządu terytorialnego, kosztów planowanych inwestycji i kosztów funkcjonowania samorządu ${ }^{12}$.

Istotą budżetu zadaniowego jest zarządzanie działalnością jednostki samorządu terytorialnego przez ujęcie tej działalności w formie zadań. Dotyczy to zarówno kompetencji ustawowych, obowiązków zleconych przez administrację rządową, jak i innych zadań wynikających $\mathrm{z}$ woli samorządu, określonych na podstawie priorytetów zawartych $\mathrm{w}$ programie gospodarczym czy strategii rozwoju oraz na podstawie potrzeb mieszkańców ${ }^{13}$.

W stosunku do układu tradycyjnego budżet zadaniowy stanowi alternatywny podziałek klasyfikacji budżetowej (dział - rozdział - paragraf), sposób opracowywania i wykonywania budżetu jednostki samorządu terytorialnego. Pozwala on na lepszą alokację zasobów finansowych i rzeczowych, a w rezultacie - właściwsze zaspokojenie potrzeb mieszkańców ${ }^{14}$.

\footnotetext{
${ }^{9}$ Budżet zadaniowy w administracji publicznej, red. M. Postuła, P. Perczyński, Ministerstwo Finansów, Warszawa 2010, s. 22.

${ }^{10}$ Budżet zadaniowy w Polsce. Reorganizacja $z$ wydatkowania na zarzadzanie pieniędzmi publicznymi, red. T. Lubińska, Difin, Warszawa 2007, s. 26.

${ }^{11}$ E. Malinowska-Misiąg, W. Misiąg, Finanse publiczne w Polsce, LexisNexis, Warszawa 2007, s. 38.

${ }^{12}$ M. Olczak, Budzet zadaniowy. Zalety i obawy, ,Wspólnota” 2000/32.

${ }^{13}$ Ibidem.

${ }^{14}$ K. Domański, B. Kozyra, J. Szołno-Koguc, Narzędzia efektywnego zarzadzania - planowanie zadań w uktadzie wieloletnim i rocznym, Brytyjski Fundusz Know How, Fundusz Współpracy, Warszawa 2000, s. 7.
} 
Tabela 1. Różnice między budżetem zadaniowym a budżetem tradycyjnym

\begin{tabular}{|c|c|}
\hline \multicolumn{1}{|c|}{ Budżet tradycyjny } & \multicolumn{1}{c|}{ Budżet zadaniowy } \\
\hline $\begin{array}{l}\text { Utrudnione powiązanie z cela- } \\
\text { nego oraz kontroli skuteczności w } \\
\text { realizacji zadań }\end{array}$ & $\begin{array}{c}\text { Sprzyja sprecyzowaniu celów jednostki samo- } \\
\text { rządu terytorialnego i monitorowaniu skuteczno- } \\
\text { ści realizacji tych celów }\end{array}$ \\
\hline $\begin{array}{l}\text { Wydatki budżetu nie są zinte- } \\
\text { growane z pozostałymi wydatkami } \\
\text { sektora publicznego }\end{array}$ & $\begin{array}{c}\text { Globalne podejście do wydatków sektora pu- } \\
\text { blicznego }\end{array}$ \\
\hline $\begin{array}{l}\text { Utrudniona hierarchizacja wy- } \\
\text { datków }\end{array}$ & $\begin{array}{l}\text { Hierarchia wydatków i instrumentów według } \\
\text { istotności rozwoju społeczno-gospodarczego } \\
\text { regionu. }\end{array}$ \\
\hline $\begin{array}{l}\text { Brak wiedzy o efektywności } \\
\text { poniesionych wydatków }\end{array}$ & $\begin{array}{l}\text { Pomiar skutków nakładów do efektów - po- } \\
\text { miar efektywności działania jednostki samorządu } \\
\text { terytorialnego }\end{array}$ \\
\hline $\begin{array}{l}\text { Ujęcie statyczne - rok budże- } \\
\text { towy. }\end{array}$ & $\begin{array}{l}\text { Podejście długofalowe - budżet roczny wyni- } \\
\text { kający z wieloletniego programowania budżeto- } \\
\text { wego }\end{array}$ \\
\hline $\begin{array}{l}\text { Klasyfikacja budżetowa wyma- } \\
\text { gająca specjalistycznej wiedzy }\end{array}$ & $\begin{array}{l}\text { Czytelna informacja o wydatkach budżeto- } \\
\text { wych }\end{array}$ \\
\hline $\begin{array}{l}\text { Dysponent administruje środ- } \\
\text { kami }\end{array}$ & $\begin{array}{l}\text { Dysponent zarządza środkami - jest odpowie- } \\
\text { dzialny za realizację programu }\end{array}$ \\
\hline
\end{tabular}

Źródło: M. Kaczmarek, Budżet zadaniowy jako sprawne narzędzie zarzadzania finansami publicznymi, http://uoo.univ.szczecin.pl/ marcink/index- (dostęp: 2.06.2015).

Budżet zadaniowy pozwala stwierdzić, które zadania są najważniejsze, oraz pozwala - za pomocą mierników - określić, w jakim stopniu zostały one wykonane. Obecnie przy opracowaniu planu wydatków budżetowych dominuje podejście kosztowe, polegające na historycznej analizie wielkości ponoszonych wydatków, a następnie na określeniu kosztów utrzymania posiadanych zasobów. Taki sposób planowania nie pozwala na uwzględnienie - w wystarczający sposób - celowości ponoszonych wydatków oraz ich efektywności ${ }^{15}$.

\section{BUDŻET ZADANIOWY W POLSCE}

Prezentując przebieg wdrażania budżetu zadaniowego w Polsce, należy oddzielić kwestie związane z pracami dotyczącymi budżetu zadaniowego na szczeblu centralnym i lokalnym, ponieważ początki tych prac odnoszą się do różnych okresów.

Prace nad budżetem zadaniowym, zwanym budżetem wyników oraz budżetem zorientowanym na efekty, rozpoczęto w Polsce w 2006 r. ${ }^{16}$. W pierwszym kwartale $2006 \mathrm{r}$. polski rząd podjął decyzję dotyczącą rozpoczęcia prac nad reformą finansów publicznych w zakresie wprowadzenia nowoczesnej metody budżetowania i zarządzania budżetem państwa, zorientowanej na cele i rezultaty oraz opartej na planowaniu wieloletnim: budże-

\footnotetext{
${ }^{15}$ Budzet zadaniowy w Polsce...op. cit., s. 9.

16 A. Kister, A. Zdroja, Budżet zadaniowy jako forma kontroli zarzadzania finansami jednostki samorzadu terytorialnego na przyktadzie jednostki oświatowej, „Zeszyty Naukowe WSEI, Ekonomia” 5/2 (2012), s. 254.
} 
cie zadaniowym ${ }^{17}$. Metoda ta miała nawiązywać do systemów stosowanych w wielu państwach OECD, a w ostatnich latach - również w licznych, nowych krajach członkowskich Unii Europejskiej. Decyzję tę podjęto w celu poprawienia skuteczności, efektywności oraz przejrzystości wydatków budżetu państwa. Dodatkowym czynnikiem przemawiającym za rozpoczęciem tych prac było to, że wprowadzenie przez kraje naszego regionu nowych metod budżetowania zorientowanego na efekty jest zalecane i promowane przez Komisję Europejską oraz instytucje międzynarodowe (m.in. OECD, Międzynarodowy Fundusz Walutowy, Bank Światowy, Organizację Narodów Zjednoczonych) oraz że jest to ważny element reformowania systemu finansów publicznych w kierunku ich unowocześnienia oraz usprawnienia ${ }^{18}$.

Prace nad reformą rozpoczęto w kwietniu 2006 r. w Kancelarii Prezesa Rady Ministrów. W pierwszej połowie 2006 r. opracowano pierwszy dokument o charakterze metodycznym, stanowiący zalążek polskiej myśli w zakresie nowoczesnych metod budżetowania w sektorze finansów publicznych ${ }^{19}$.

Znaczącym krokiem w przygotowaniu odpowiednich warunków do rozpoczęcia reformy było umieszczenie zapisów, dotyczących budżetowania zadaniowego w podstawowych dokumentach programowych i strategicznych rządu - Krajowym Programie Reform, Strategii Rozwoju Kraju, a także rozpoczęcie starań, aby wydatki na tę reformę zostały ujęte w ramach Europejskiego Funduszu Społecznego ${ }^{20}$.

Na początku drugiej połowy 2006 r. prace nad reformą weszły w kolejny etap o charakterze operacyjnym, w którego ramach zdecydowano, aby na podstawie opracowanej metodyki podjąć próbę sporządzenia pierwszego modelu budżetu zadaniowego państwa w zakresie dwóch części budżetowych: części 28 Nauka oraz części 38 Szkolnictwo Wyższe. W grudniu $2006 \mathrm{r}$. wprowadzono pierwsze zapisy dotyczące budżetu zadaniowego do „Ustawy z 27 sierpnia 2009 r. o finansach publicznych”21 (zwanej dalej: Ustawa o finansach publicznych): nałożenie na dysponentów obowiązku sporządzania zadaniowego planu wydatków ${ }^{22}$ oraz przygotowania informacji o wykonaniu zadań w ramach sprawozdania o wykonaniu budżetu państwa ${ }^{23}$.

W drugim kwartale 2007 r. opracowano wkład do projektu Rozporządzenia Ministra Finansów z 18 maja 2008 r. w sprawie szczegółowego sposobu i terminów opracowania materiałów do projektu ustawy budżetowej na rok 2008 w zakresie zasad sporządzania materiałów do zadaniowego planu wydatków.

W trzecim kwartale $2007 \mathrm{r}$. w uzasadnieniu do projektu ustawy budżetowej na $2008 \mathrm{r}$. zaprezentowano budżety w układzie zadaniowym większości dysponentów części budżetowych. Pod koniec stycznia 2008 r. zadania związane z przygotowaniem metodologii i wdrożeniem budżetu zadaniowego zostały przeniesione z Kancelarii Prezesa Rady Ministrów do Ministerstwa Finansów i od tego momentu:

\footnotetext{
${ }^{17}$ Szerzej: Ministerstwo Finansów, Budżet zadaniowy (e-szkolenie dla Grupy Strategicznej), www.mf.gov.pl (dostęp: 2.06 2015).

${ }^{18}$ Budżet zadaniowy w administracji publicznej...op. cit., s. 174.

${ }^{19}$ Szerzej: Ministerstwo Finansów, op. cit.

${ }^{20}$ A. Kister, A. Zbroja, op. cit., s 254.

${ }^{21}$ Dz.U. 2013, poz. 885 ze zm.

${ }^{22}$ Art. 124 pkt 9 ustawy o finansach publicznych.

${ }^{23}$ Art. 158 ust. 3 pkt 9 ustawy o finansach publicznych.
} 
- $\quad$ opracowano harmonogram prac nad budżetem zadaniowym na lata 20082015, który zakładał, że budżet w układzie zadaniowym po raz pierwszy zostanie zaprezentowany $\mathrm{w}$ ustawie budżetowej równolegle $\mathrm{z}$ budżetem tradycyjnym na 2013 rok;

- opracowano nową metodologię opartą na funkcjonalnym i zadaniowym układzie budżetu, którą zaprezentowano w Rozporządzeniu Ministra Finansów z 9 maja 2008 r. w sprawie szczegółowego sposobu, trybu i terminów opracowania materiałów do projektu ustawy budżetowej na rok 2009²4;

- $\quad$ przygotowano informację do sprawozdania z wykonania ustawy budżetowej za rok 2007 (stanowiącą wykonanie zapisów art. 158 ust. 3 pkt 9 „Ustawy o finansach publicznych”) obejmującą wykonanie budżetu Ministerstwa Nauki i Szkolnictwa Wyższego w układzie zadaniowym;

- przygotowano podstawy prawne dla dalszych prac nad budżetem zadaniowym - nową ustawę o finansach publicznych,

- przygotowano i wdrożono procedurę koordynacji prac nad budżetem zadaniowym;- przygotowano standardy definiowania celów;

- rozpoczęto prace nad stworzeniem bazy mierników dla poszczególnych funkcji państwa;

- $\quad$ opracowano noty budżetowe na kolejne lata.

Biorąc pod uwagę wyjątkowo złożony (i z natury rzeczy - wieloletni) oraz nowatorski charakter reformy, a także wynikającą $\mathrm{z}$ tego potrzebę zapewnienia bezpieczeństwa systemu finansów publicznych, szczególnego znaczenia nabrał fakt, że pierwsze pilotażowe prace nad opracowaniem wydatków w układzie zadaniowym postanowiono umieścić w Uzasadnieniu do projektu ustawy budżetowej na 2007 r. Było to szczególnie znamienne, zważywszy na to, że w czasie realizacji tego pilotażu nie istniały jeszcze żadne prawnie obowiązujące zapisy ustawowe dotyczące budżetu zadaniowego ${ }^{25}$.

Pierwszy plan wydatków, w podziale na zadania skierowany do dysponentów wszystkich części budżetowych, został opracowany na rok 2009. Plan ten zawierał także projekt wydatków na lata 2010 i 2011. Zadaniowy plan wydatków na lata 2009-2011 został ułożony według 22 podstawowych funkcji państwa, które grupują wydatki wszystkich dysponentów części budżetowych według podstawowych działalności - obszarów polityki, prowadzonej przez państwo ${ }^{26}$.

W celu uniknięcia nadmiernej szczegółowości zadań i osiągnięcia odpowiedniej przejrzystości budżetu dla każdej z 22 funkcji wyodrębniono zadania, które syntetycznie grupują działania, służące osiągnięciu jednego celu.

Pierwsze próby zmian formy budżetu pojawiły się w polskich samorządach w latach dziewięćdziesiątych XX wieku. Początki wprowadzania budżetu zadaniowego w Polsce sięgają 1994 r., kiedy w Krakowie rozpoczęto reformę metody planowania wydatków. Kolejnymi dużymi miastami były: Lublin, Szczecin i Poznań. Istotne znaczenie miało tu wsparcie z Programu Partnerstwa dla Samorządu (LGPP) sponsorowane przez Amerykańską Agencję Rozwoju Międzynarodowego (USAID, United States Agency for International Development). Program LGPP miał za zadanie wzmocnić zdolność polskich gmin do

\footnotetext{
${ }^{24}$ Dz. U. 2008, nr 249, poz. 537.

${ }^{25}$ Budżet zadaniowy $w$ administracji publicznej...op. cit., s. 174-175.

${ }^{26}$ Ibidem.
} 
skutecznego świadczenia usług i zarządzania własnymi zasobami oraz zwiększyć udział społeczności lokalnych w podejmowaniu decyzji na ich terenie. Główną formą działalności LGPP było wdrażanie w gminach i powiatach (łącznie ponad 200 jednostek samorządu terytorialnego) nowoczesnych narzędzi i metod zarządzania.

W latach 1999-2000, dzięki szkoleniom, a także bezpośredniej pomocy z tego programu, 38 samorządów przygotowało swoje budżety w formie budżetów zadań. Były to zarówno duże miasta, jak i mniejsze gminy ${ }^{27}$.

W latach 2002-2003 przeprowadzono Program Rozwoju Instytucjonalnego (PRI) adresowany do urzędów administracji publicznej. Program ten - obok ogólnopolskiego Programu Szkoleniowego - był wkładem Ministerstwa Spraw Wewnętrznych i Administracji (MSWiA) w realizację rządowego Programu Aktywizacji Obszarów Wiejskich współfinansowanego ze środków Banku Światowego.

Program Rozwoju Instytucjonalnego przeprowadzono w 30 jednostkach samorządu terytorialnego oraz 3 urzędach wojewódzkich przez konsultantów Małopolskiej Szkoły Administracji Publicznej, Akademii Ekonomicznej w Krakowie i Canadian Urban Institute, we współpracy z MSWiA. Jednym z projektów realizowanych w ramach PRI było wdrażanie budżetu zadaniowego ${ }^{28}$.

W 2009 r. wdrażaniem budżetu zadaniowego objęto 6 powiatów i 11 gmin województwa zachodniopomorskiego w ramach Priorytetu V (Dobre Rządzenie) Programu Operacyjnego Kapitał Ludzki (Działanie 5.2. Wzmocnienie potencjału administracji samorządowej, Poddziałanie 5.2.1. Modernizacja zarządzania w administracji samorządowej) sfinansowanego ze środków Europejskiego Funduszu Społecznego. Prace wdrożeniowe były realizowane przez zespół pracowników Uniwersytetu Szczecińskiego ${ }^{29}$.

W procesie tworzenia budżetu zadaniowego na szczeblu samorządowym istotną rolę przywiązuje się do szerokich konsultacji społecznych, opisu dokonanych wyborów oraz proponuje się wariantowe prezentacje ${ }^{30}$. Obecnie w praktyce samorządowej bardzo różnie przedstawia się zakres tego budżetu: od pojedynczych dziedzin przez sam urząd, na przykład gminy, do pełnego zakresu - to znaczy budżet zadaniowy obejmujący urząd oraz wszystkie podległe mu jednostki organizacyjne.

\section{CELE I ZADANIA BUDŻETU ORAZ JEGO MIERNIKI}

Wprowadzenie budżetu zadaniowego stanowi jeden z elementów reformy sektora publicznego, która ma na celu jego urynkowienie, poprawę efektywności i jakości świadczonych przez niego usług. Celem w tym wypadku jest przede wszystkim zwiększanie efektywności wydatkowania środków publicznych. W kwestii finansów publicznych,

\footnotetext{
${ }^{27}$ Budzet wtadz lokalnych, red. S. Owsiak, PWE, Warszawa 2002, s. 131.

${ }^{28}$ Budzet zadaniowy $w$ Polsce...op. cit., s. 21.

${ }^{29}$ J. Sawicka, J. Rykowska, Harmonizacja planowania strategicznego rozwoju z planowaniem budżetowym, [w]: Budżet zadaniowy jako nowoczesne narzędzie zarządzania gospodarka narodowa, red. A. Siedlecka, PSW, Biała Podlaska 2011, s. 63.

${ }^{30}$ E. Chojna-Duch, Polskie prawo finansowe. Finanse publiczne, Wydawnictwo Prawnicze LexisNexis, Warszawa 2006, s. 254.
} 
zarówno tych centralnych, jak i samorządowych, budżet zadaniowy daje takie możliwości, ponieważ $\dot{z}^{31}$ :

- $\quad$ eliminuje dublujące się cele poszczególnych resortów w budżecie centralnym;

- umożliwia niefinansowanie celów już wcześniej zrealizowanych;

- $\quad$ zwiększa jawność oraz przejrzystość budżetu państwa i budżetów jednostek samorządu terytorialnego;

- $\quad$ stwarza możliwość kontrolowania wydatkowania środków oraz osiąganych efektów;

- $\quad$ pozwala finansować zadania w wieloletnim okresie;

- umożliwia wybór rangi poszczególnych celów oraz wybór tych, które najlepiej służą wzrostowi gospodarczemu;

- zapewnia spójność między planowaniem strategicznym a podejmowanymi działaniami operacyjnymi;

- $\quad$ umożliwia globalne podejście do zadań i środków publicznych;

- pozwala poszczególnym dysydentom (resortom, wojewodom) na prowadzenie własnej strategii zarządzania publicznymi środkami przez opracowywanie planów operacyjnych, w których są określone działania.

Procedura budżetowania zadaniowego pozwala na: ustalanie pożądanych wyników w odniesieniu do usług, planowanie, w jaki sposób osiągnąć te wyniki, ustalanie mierników wyniku oraz oceny i sprawozdawczości, jak również poprawianie wyników. Dzięki tak rozumianemu budżetowi można osiągnąć następujące efekty ${ }^{32}$ :

- $\quad$ powiązanie rozdziału środków z jasno wyrażonymi oczekiwaniami;

- $\quad$ określenie procedur, które powodują, że decyzje o podziale środków są przejrzyste;

- $\quad$ podział obowiązków w zakresie realizacji poszczególnych zadań pomiędzy konkretne osoby w ramach struktur samorządowych oraz opracowanie mechanizmów i sprawozdań pozwalających na kontrolowanie wykonania obowiązków w stosunku do oczekiwanych wyników;

- wypracowanie mechanizmów oceny wyników w celu kontrolowania skuteczności wydatkowania środków na dane zadanie lub program ${ }^{33}$.

Z budżetem zadaniowym związane są trzy podstawowe pojęcia, a mianowicie: zadanie, cel i miernik (rys. 1$)^{34}$.

\footnotetext{
${ }^{31}$ M. Podstawka, J. Dynowska, P. Góralski, E. Rudowicz, Przygotowanie administracji rzadowej do sporzadzania zadaniowego planu wydatków na rok 2008. Materiaty szkoleniowe, Kancelaria Prezesa Rady Ministrów, Warszawa 2007, s. 7

${ }^{32}$ D. Bartkowska-Nowak, J. Nowak, J. Webb, Zarządzanie w gminie. Podręcznik doskonalenia umiejętności kierowniczych, Brytyjski Fundusz Know-How - Fundusz Współpracy, Warszawa 1998, s. 176.

${ }^{33}$ Ibidem.

${ }^{34}$ Ibidem.
} 
Rys. 1. Filary budżetu zadaniowego

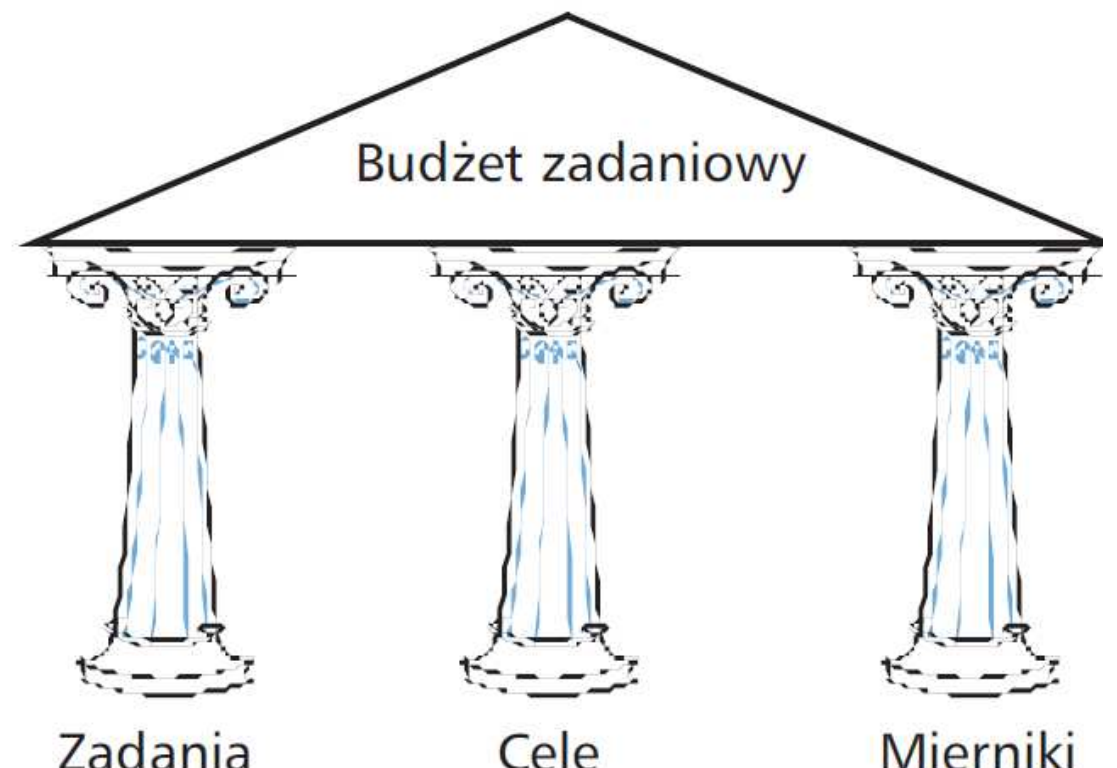

Źródło: opracowanie własne na podstawie: P. Oleksyk, Cele i mierniki w budżecie zadaniowym (Budżet zadaniowy- portal wiedzy), www.budżet-zadaniowy.info (dostęp: 2.06.2015).

W ujęciu merytorycznym zadanie stanowi elementarną, a zarazem centralną kategorię budżetu opracowanego w nowatorski sposób. Najważniejszą cechą zadania jest to, że obejmuje ono działalność jednorodną. Ta cecha pozwala jasno określić cel realizacji zadania, stopień jego wykonania (efekt) oraz ponoszone koszty.

Jednorodność działalności, ujętej w zadaniu, pozwala na kategoryzację zadań według rożnych kryteriów, przy czym najważniejsze z nich to kryterium przedmiotowe.

Kategoryzacja zadań według określonych kryteriów łączy się ściśle z ich nazwami. Złożoność działalności ujmowanej w zadania może zmusić do wyodrębniania podzadań. Zdefiniowanie zadań należy do jednego z najtrudniejszych wyzwań w budżecie zadaniowym. Wynika to $\mathrm{z}$ tego, że w rzeczywistości nie jest łatwo wyodrębnić jednorodną działalność, ponieważ różne obszary aktywności władz publicznych zachodzą na siebie ${ }^{35}$. Fundamentalnym problemem dla skutecznego wykorzystywania zalet metody budżetu zadaniowego jest wyodrębnienie zadań wykonywanych w sposób powtarzalny i zadań nowych ${ }^{36}$.

Zadanie budżetowe można rozumieć jako czynność do wykonania, której efektem będzie realizacja strategicznych celów jednostki samorządu terytorialnego (ekonomicznych, społecznych) oraz zaspokojenie potrzeb jej mieszkańców i podmiotów gospodarczych

\footnotetext{
${ }^{35}$ Szerzej M. Korolewska, Budżet zadaniowy narzędziem realizacji polityki budżetowej, „Studia BAS” 23/3 (2010), s. 197-211.

${ }^{36}$ Budżet zadaniowy w administracji publicznej...op. cit., s. 45-47.
} 
funkcjonujących na jej terytorium. Oczywiste jest, że zadania ujęte w budżecie zadaniowym powinny być zgodne $\mathrm{z}$ budżetem uchwalanym w układzie klasyfikacji budżetowej ${ }^{37}$.

Według ogólnej definicji cel to pożądany przyszły stan rzeczy, który pragnie osiągnąć osoba lub organizacja ${ }^{38}$. Innymi słowy, jest to pożądany stan docelowy podejmowanych działań. Dobór odpowiednich celów, a także ich właściwe sformułowanie mają fundamentalne znaczenie dla skutecznego funkcjonowania budżetu zadaniowego ${ }^{39}$.

Właściwie obrany cel umożliwia jednoznaczne i przejrzyste określenie przyczyny wydatkowania środków pieniężnych na dane zadanie i związanych z nim potrzeb społecznogospodarczych oraz ułatwia ocenę stopnia jego realizacji. Tym samym wartościuje skuteczność i efektywność działania instytucji publicznej, jaką jest jednostka samorządu terytorialnego. Podczas formułowania celów należy wziąć pod uwagę ${ }^{40}$ :

- jakość i liczbę realizowanych zadań;

- $\quad$ stopień realizacji zadań;

- terminy wykonalności;

- efektywność.

Właściwe określenie stopnia realizacji danego zadania oraz wykonania budżetu determinuje stworzenie mierników (wskaźników).

Konstrukcja mierników adekwatnych do realizowanych celów jest uznawana za kluczową sprawę dla poprawy efektywności zarządzania gospodarką finansową jednostki samorządu terytorialnego, a jednocześnie jest ona najtrudniejsza. Mierniki powinny służyć ocenie realizacji zadania, podzadania pod względem ${ }^{41}$ :

- $\quad$ istotności zadania;

- $\quad$ skuteczności;

- $\quad$ efektywności;

- użyteczności;

- trwałości.

- Biorąc pod uwagę tę różnorodność możliwych do zastosowania mierników, warto zastanowić się, które z nich i w jakich przypadkach są wykorzystywane. Do najczęściej wykorzystywanych mierników w ramach klasyfikacji opracowanej przez OECD zalicza się ${ }^{42}$ :

- jakość (miernik pozwalający ocenić, jak została wykonana praca zgodność z wymaganiami lub standardami);

- $\quad$ terminowość (miernik tempa i czasu pracy);

- $\quad$ koszt (miernik nominalnej wartości nakładów, wykorzystanych do wytworzenia wyników);

\footnotetext{
${ }^{37}$ S. Kańduła, I. Kijek, Budżet zadaniowy w gospodarce jednostek samorzadu terytorialnego, ,Zeszyty Naukowe Uniwersytetu Szczecińskiego" 2008/500, s. 333.

${ }^{38}$ T. Lubińska, T. Strąk, A. Lozan -Platonoff, M. Będzieszak, Budzet zadaniowy dla Polski - efekty prac, „Zeszyty Naukowe Uniwersytetu Szczecińskiego" 2008/489, s. 230.

${ }^{39}$ Ibidem.

${ }^{40}$ S. Kańduła, I. Kijek, op. cit., s. 333.

${ }^{41}$ Ibidem.

${ }^{42}$ Budżet zadaniowy $w$ administracji publicznej... op. cit., s. 45-47.
} 
- wydajność (miernik mierzący ilość wykorzystanych nakładów w procesie wytworzenia i dostarczenia wyników odniesiony do odpowiedniego kryterium).

Na podstawie tej klasyfikacji stworzono zestaw mierników obejmujący ${ }^{43}$ :

- mierniki oddziaływania mierzące długofalowe konsekwencje realizacji zadania. Mogą one mierzyć bezpośrednie skutki wdrażania zadania, ale ujawniające się po dłuższym czasie. Mierniki oddziaływania odnoszą się czasem do wartości, które tylko w części są efektem realizacji zadania (na efekty wpływają także inne, zewnętrzne czynniki). Oddziaływaniem może być stopa bezrobocia;

- mierniki rezultatu mierzące efekty uzyskane w wyniku działań objętych zadaniem lub podzadaniem, realizowanych za pomocą odpowiednich wydatków, na poziomie zadania/podzadania/działania. Mierzą zatem skutki podejmowanych działań. Przykładem rezultatu może być liczba bezrobotnych, którzy znaleźli pracę po odbytym szkoleniu;

- mierniki produktu odzwierciedlające wykonanie danego zadania w krótkim okresie i pokazują konkretne dobra i usługi wyprodukowane przez sektor publiczny. Przykładem produktu może być liczba przeszkolonych bezrobotnych.

Należy również zauważyć, że mierniki powinny służyć ocenie realizacji zadania i podzadania pod względem jego skuteczności i efektywności. Dla budżetu zadaniowego szczególną wagę mają zatem mierniki:

- $\quad$ skuteczności mierzące stopień osiągnięcia zamierzonych celów - mogą one mieć zastosowanie na wszystkich szczeblach klasyfikacji zadaniowej, na przykład odsetek uczniów szkoły, którzy zdali egzamin gimnazjalny;

- efektywności mierzące zależność między nakładami i osiągniętymi efektami (wynikami), na przykład wydatki oświatowe w przeliczeniu na jednego ucznia.

Bez względu na typologię i klasyfikację wybór miernika do pomiaru stopnia realizacji celów/zadań powinien być determinowany następującymi czynnikami:

- określenie misji i celów danego zadania lub programu;

- identyfikacja, do czego służyć będzie informacja otrzymana w wyniku zastosowania danego miernika;

- zidentyfikowanie, które aspekty wykonania zadań będą podlegać pomiarowi;

- $\quad$ wybór kryterium oceny;

- $\quad$ wyjaśnienie przyczyn dobrego lub złego wykonania zadań;

- zaprezentowanie wyników dokonanych pomiarów.

\section{PODSUMOWANIE}

Budżet zadaniowy zaczyna rzeczywiście funkcjonować dopiero wtedy, gdy zadania zostają prawidłowo rozpisane na konkretne cele, te stają się wtedy podstawą podziału środków, a za pomocą mierników zaczyna się oceniać funkcjonowanie instytucji publicznych. Dopiero wówczas instytucjom publicznym przedkłada się jasne wytyczne i środki

\footnotetext{
${ }^{43}$ Budżet zadaniowy w Polsce... op. cit., s. 40
} 
do realizacji celów, ale równocześnie obciąża się je pełną odpowiedzialnością za ich skuteczne wykorzystanie.

Budżet zadaniowy pozwala na ustalenie, które zadania są najważniejsze dla realizacji określonych celów oraz za pomocą mierników ukazuje, w jakim stopniu zostały one wykonane. Aktualnie w planowaniu wydatków jednostek samorządu terytorialnego dominuje podejście kosztowe, polegające na historycznej analizie wielkości ponoszonych wydatków, a następnie na określeniu kosztów utrzymania posiadanych zasobów.

Budżet zadaniowy nie stanowi obecnie przedmiotu regulacji prawa finansowego w odniesieniu do jednostek samorządu terytorialnego. Funkcjonowanie budżetu zadaniowego w niektórych jednostkach samorządowych wynika wyłącznie z ich inicjatywy.

\section{LITERATURA}

[1] Bartkowska-Nowak B., Nowak J., Webb J., Zarzadzanie w gminie. Podręcznik doskonalenia umiejętności kierowniczych, Brytyjski Fundusz Know-How - Fundusz Współpracy, Warszawa 1998.

[2] Budzet zadaniowy w Polsce. Reorganizacja z wydatkowania na zarzadzanie pieniędzmi publicznymi, red. T. Lubińska, Difin, Warszawa 2007.

[3] Chojna-Duch E., Polskie prawo finansowe. Finanse publiczne, Wydawnictwo Prawnicze LexisNexis, Warszawa 2006.

[4] Domański K., Kozyra B., Szołno-Koguc J., Narzędzia efektywnego zarzadzania - planowanie zadań w uktadzie wieloletnim i rocznym, Brytyjski Fundusz Know How, Fundusz Współpracy, Warszawa 2000.

[5] Dziekański P., Gospodarka finansowa powiatów województwa świętokrzyskiego w świetle polskiego prawa i danych ekonomicznych, [w:] Ekonomiczne i organizacyjne instrumenty wspierania rozwoju lokalnego i regionalnego. Przedsiębiorczość, instytucje wsparcia i gospodarka finansowa, red. B. Filipiak, „Zeszyty Naukowe” 500, „Ekonomiczne Problemy Usług” 2008/21.

[6] Dziekański P., Wpływ polityki budżetowej jednostek samorzadu terytorialnego na rozwój regionu świętokrzyskiego, [w:] Konkurencyjność i innowacyjność regionów w warunkach globalizacji i metropolizacji przestrzeni, red. J. Kot, Akademia Świętokrzyska w Kielcach, Wydział Zarządzania i Administracji, Instytut Ekonomii, Kielce 2007.

[7] Jastrzębska M., Finanse jednostek samorzadu terytorialnego, Wolters Kluwer Polska, Warszawa 2012.

[8] Kaczmarek M., Budżet zadaniowy jako sprawne narzędzie zarządzania finansami publiczny$m i$, http://uoo.univ.szczecin.pl/ marcink/index- (dostęp: 2.06.2015).

[9] Kańduła S., Kijek I., Budzet zadaniowy w gospodarce jednostek samorzqdu terytorialnego, „Zeszyty Naukowe Uniwersytetu Szczecińskiego” 2008/500.

[10] Kister A., Zdroja A., Budżet zadaniowy jako forma kontroli zarzadzania finansami jednostki samorządu terytorialnego na przyktadzie jednostki oświatowej, ,Zeszyty Naukowe WSEI, Ekonomia" 5/2 (2012).

[11] Komunikat Ministra Finansów z 12 kwietnia 2010 r. w sprawie standardów definiowania celów dla jednostek sektora finansów publicznych w zadaniowym planie wydatków na rok 2011 (DzUrz MF 2010, nr 5, poz. 22).

[12] Konstytucja Rzeczypospolitej Polskiej z 2 kwietnia 1997 r. (DzU 1997, nr 78, poz. 483 ze zm.).

[13] Korolewska M., Budżet zadaniowy narzędziem realizacji polityki budżetowej, „Studia BAS” $23 / 3(2010)$.

[14] Lubińska T., Strąk T., Lozan-Platonoff A., Będzieszak M., Budżet zadaniowy dla Polski efekty prac, ,Zeszyty Naukowe Uniwersytetu Szczecińskiego” 2008/489.

[15] Malinowska-Misiąg E., Misiąg W., Finanse publiczne w Polsce, LexisNexis, Warszawa 2007. 
[16] Ministerstwo Finansów, Budżet zadaniowy (e-szkolenie dla Grupy Strategicznej), www.mf.gov.pl (dostęp: 2.06 2015).

[17] Olczak M., Budżet zadaniowy. Zalety i obawy, „Wspólnota” 2000/32.

[18] Olak A., Terytorialny marketing mix - produkt, cena, dystrybucja, promocja, [w:] A. Olak, P. Dziekański, S. Pytka, Marketing Terytorialny - gmina i jej promocja, Multiprint, S.R.O, Kośice-Ostrowiec-Zagnańsk 2014.

[19] Oleksyk P., Cele i mierniki w budżecie zadaniowym (Budżet zadaniowy - portal wiedzy), www.budżet-zadaniowy.info (dostęp: 2.06.2015).

[20] Owsiak S., Budżet wtadz lokalnych, PWE, Warszawa 2002.

[21] Postuła M., Budżet zadaniowy w Polsce - osiagnięcia $i$ wyzwania, Biuro Analiz Sejmowych Kancelarii Sejmu, „Studia BAS” 33/1 (2013).

[22] Postuła M., Perczyński P., Budżet zadaniowy w administracji publicznej, Ministerstwo Finansów, Warszawa 2010.

[23] Podstawka M., Dynowska J., Góralski P., Rudowicz E., Przygotowanie administracji rzadowej do sporzadzania zadaniowego planu wydatków na rok 2008, Materiaty szkoleniowe, Kancelaria Prezesa Rady Ministrów, Warszawa 2007.

[24] Rozporządzenie Ministra Finansów z 18 maja 2007 r. w sprawie szczegółowego sposobu, trybu i terminów opracowania materiałów do projektu ustawy budżetowej na rok 2008 (DzU nr 94, poz. 628).

[25] Rozporządzenia Ministra Finansów z 9 maja 2008 r. w sprawie szczegółowego sposobu, trybu i terminów opracowania materiałów do projektu ustawy budżetowej na rok 2009 (DzU 2008, nr 249, poz. 537).

[26] Sawicka J., Rykowska J., Harmonizacja planowania strategicznego rozwoju z planowaniem budżetowym [w]: Budżet zadaniowy jako nowoczesne narzędzie zarzadzania gospodarka narodowa, red. A. Siedlecka, PSW, Biała Podlaska 2011.

[27] Sowa B., Budżet jednostki samorzadu terytorialnego jako podstawa planowania przedsięwzięć inwestycyjnych, [w:] Przedsiębiorczość. Uwarunkowania i przejawy w procesie funkcjonowania samorzadu terytorialnego, red. K. Jaremczuk, L. Kliszczak, W. Kalita, R. Kostelecki, M. Kurek, W. Kuźniar, P. Niemczuk, B. Sowa, J. Strojny, Wyższa Szkoła Prawa i Administracji w Przemyślu, Przemyśl-Rzeszów 2012.

[28] Sowa B., Gospodarka finansowa gminy-wybrane aspekty, [w:] Samorzad gminy w świetle badań empirycznych, red. J. Posłuszny, Z. Czarnik, Wyższa Szkoła Prawa i Administracji, Przemyśl-Rzeszów 2014.

[29] Szpringer Z., Budżet zadaniowy Polski w świetle doświadczeń międzynarodowych, Biuro Analiz Sejmowych Kancelarii Sejmu, „Studia BAS” 33/1 (2013).

[30] Ustawa budzetowa na rok 2011. Uzasadnienie, t. II: Omówienie: wydatki państwa w układzie zadaniowym, Rada Ministrów, Warszawa 2010.

[31] Ustawa z 27 sierpnia 2009 r. o finansach publicznych (DzU 2013, poz. 885 ze zm.).

[32] Uzasadnienie do projektu ustawy o finansach publicznych, Druk Sejmowy nr 1181.

[33] Uzasadnienie do ustawy budżetowej na rok 2009 w uktadzie zadaniowym, Rada Ministrów, Warszawa 2008.

\section{PERFORMANCE BUDGET AS A NEW METHOD OF PUBLIC FUNDS MANAGEMENT}

Reactivated in Poland in 1990, the local government is based on the experience of the inter-government and local governments in Western Europe. The division of public tasks in the resulting structures between government bodies and municipalities, counties and state governments also raises the need for allocation of public revenues. They are indeed a key material base of public tasks. 
It should be emphasized that the efficiency, success and activity of local authorities in the development of a unit depends to a large degree on the abilities, qualifications and experience of the local authorities. One of more important tools is, inter alia, a possibility of forming municipal budget, municipal property management and possibility of supporting small and medium enterprises. Obviously, financial resources, which are the basis of planned tasks realization, are the indispensable factor and the catalyst of the local development.

The planning and realization of expenditure from public funds is one of the biggest challenges connected with public management. During planning, the best allocation of public funds should be chosen, having regard to reported social and economic needs.

The aim of this article is to present the performance budget as the new method of public funds management, starting with the central budget and ending with the lowest level budgets. Particular attention has been paid to aims and tasks of the budget as well as to its meter which enable the assessment of its efficiency.

Keywords: government, local authorities, public finance, the budget task force, public tasks

\section{DOI: 10.7862/rz.2015.mmr.41}

Tekst złożono w redakcji: sierpień 2015

Przyjęto do druku: wrzesień 2015 